DOI https://doi.org/10.32841/2409-1154.2021.49-1.1

\author{
Baibakova I. M., \\ Candidate of Philological Sciences, Associate Professor, \\ Associate Professor at the Foreign Languages Department \\ Lviv Polytechnic National University
}

\author{
Hasko O.L., \\ Candidate of Philological Sciences, Associate Professor, \\ Associate Professor at the Foreign Languages Department \\ Lviv Polytechnic National University
}

\title{
LANGUAGE COMMUNICATION THEORY WITHIN PROFESSIONAL DISCOURSE
}

Summary. Communication theory has been paid much attention to. In this paper it is considered within professional discourse studies being of direct practical job-related character. The paper is aimed at regarding communication theory in the context of professional discourse studies.

Being a unique mental capacity, characteristic only of humans, language is a complex system which includes sounds, written symbols/printed characters as well as grammar rules used in communication processes for sharing information, exchanging thoughts and expressing feelings.

Distinguishing features of a human language, namely, reflexivity, displacement, arbitrariness, productivity, cultural transmission and duality should be taken into consideration since communication cannot exist without knowing a language.

The theory of communication is directly related to discourse in general and professional discourse in particular. The latter belonging to verbal communication based on words, which refers to speaking, reading, writing and aural comprehension. All these aspects should be paid attention to in the process of professional discourse studies. Discourse studies dealing with the analysis of the use of spoken or written language in a social communicative context with regard to cognitive process also rely on such factors as the structure of lessons and its variations, differential treatment, sharing time etc.

Professional discourse studies based on the theory of communication are aimed at mastering:

- intraprofessional discourse i.e. discourse within a specific profession representing communication among academics;

- interprofessional discourse i.e. discourse between individuals as representatives of different professions;

- professional-lay discourse reflecting e.g. lawyers/ their clients or advertisers/ their potential customers' communication.

Analysis and training of professional discourse is part and parcel of the curriculum incorporating courses "English for specific purposes", "English for Academics", "Professional English", "Rhetoric", "Intercultural Communication" etc.

Key words: theory of communication, applied linguistics, intercultural communication, professional discourse, cognitive process.

The problem being under consideration and its practical application. Communication theory has been paid much attention to. In this paper it is considered within professional discourse studies being of direct practical job-related character.

Analysis of the recent publications on the issue. Yu Genyuan in the work "The Basic Theories of Applied Linguistics" argues that communication theory takes a leading role in the basic theories of applied linguistics. According to the author it is also a link between linguistics per se and applied linguistics since "besides the abilities of linguistic knowledge, linguistic communication and linguistic research, there lies on a higher level a more important ability of fully utilizing linguistic abilities, which is the creative ability of language" [1].

In the publication 'Communication Theory at the Center: Ventriloquism and the Communicative Constitution of Reality' by François Cooren communication is metaphorically regarded as a form of ventriloquism translating 'our capacity to make other beings say or do things while we speak, write, or, more generally, conduct ourselves' which refers to rhetoric, semiotics, phenomenology, cybernetics, sociopsychology, sociocultural theory etc. maintaining a certain ontological and epistemological coherence [2].

The aim of the paper. The paper is aimed at regarding language communication theory in the context of professional discourse studies.

The body of the paper. Ever since we are born, we learn how to communicate. Communication is a process whereby meaning is defined and shared between living organisms. The term living organisms indicates the fact that an ability to communicate does not refer only to human beings. Every piece of information exchanged between living organisms - i.e. the transmission of signals that involve a living sender and receiver can be considered a form of communication. Even primitive creatures such as corals are competent to communicate. There are two major types of human communication, verbal and nonverbal that can also be discussed within the context of intercultural communication, for the culture we live in determines the way in which we communicate, and the means of communication modifies our culture [3].

Anthroposemiotics is a field of study dedicated to understanding how people communicate. Before discussing particular types of communication, however, one has to be aware of the fact that communication cannot exist without knowing a language. It is very difficult to define language in a few words, as lots of attempts to determine what language and its origin is have been taken. We stick to the most commonly known and understood definition, that is the following: language is a complex system of arbitrary signals, (such as sounds, gestures or written symbols), including grammar rules used in communication, through which a message, including information about thoughts and feelings, is conveyed [4]. Despite it 
being a system, language is also a unique mental capacity, characteristic only of humans.

There are six distinguishing features of a human language: reflexivity, displacement, arbitrariness, productivity, cultural transmission and duality. The following analyses are based on the research of G. Yule's (2010). Let us have a closer look at reflexivity first [5].

Due to the property of reflexivity people can use language to think and talk about language itself. Without this general ability, we would not be able to identify any of the other properties of human language. Reflexivity is the defining feature of natural languages.

Another one is displacement. On account of this ability, humans can refer to past and future. We can effectively relate to occurrences that are far removed in time and space. This property enables people to talk about events and things not present in the immediate environment or whose existence we cannot scientifically prove (e.g. fairies, angels, heaven, hell, etc).

Arbitrariness is a relationship between linguistic signs and objects in the world. There is no natural reason why a particular sign should be attached to a particular concept [6].

Human languages allow speakers to create novel, never-before-heard utterances that others can understand. By manipulating their linguistic resources, they are able to describe new objects and circumstances. This property is described as productivity. It provides humans with the ability of a continual creation of new expressions and sentences.

Another distinguishing property of human language is cultural transmission. It is a process in which a language is passed on from one generation to the next. This is different from many animal communication systems where the animal is born knowing their entire system, e.g. bees are born with the knowledge concerning how to dance. Animals are born with a set of specific signals that are produced instinctively. Human infants, growing up in isolation, produce no instinctive languages.

The last distinguishing human language property is called duality. It means that human language is organized at two levels simultaneously. In speech production, at one level, we have distinct sounds, and, at another level, we have distinct meanings.

As Fromkin et al (2010) notice, people live in a world of language. That is why language discourse is one of the most important categories through which the majority of communication passes. To study discourse is to analyze the use of spoken or written language in a social communicative context and it is on what the theory of communication rests. As we know the term 'communication' is derived from Latin "communication", meaning conversation, an exchange, contact and the first type out of two major types of communication is verbal communication. Verbal communication involves using speech to exchange information with others. In other words, verbal communication is based on words, which are passed on either in speaking, reading or writing.

Words alone have no meaning. Only people can put meaning into words. As meaning is assigned to words, language develops, which leads to the development of speaking. Speaking can be looked at in two major areas: interpersonal and public speaking.

Since the majority of speaking is an interpersonal process, to communicate effectively people are not only supposed to know the language well, but also learn to relate to others. Z. Nęcki defines interpersonal communication as an exchange of verbal, vocal and nonverbal signals undertaken in a specific context so as to achieve a better level of cooperation [7]. The lack of successful communication is one of the major barriers on the road to effective group collaboration.

The other area of speaking is public speaking. Public speaking is the process of speaking to a group of people in an organized, intentional manner intended to inform, influence, or entertain the listeners. The term oratory, the logic and practice persuasive public speaking, may be alternatively used. Rhetoric, classically the theoretical basis for the art of oratory, is the art of using words effectively.

People do not communicate through words only. Being humans, we are equipped with senses which play a huge role in interpersonal communication. We can unquestionably speak and hear, but we also move, touch and feel. A process of sending primarily wordless messages is called nonverbal communication. Nonverbal communication includes facial expressions, eye contact, touch, body posture and motions, and positioning within groups. Meaning can also be transferred through object or artifacts (such as clothing, hairstyles or architecture), symbols, and icons (or graphics). A very important feature of nonverbal communication, present in speech, is paralanguage. The study of paralanguage is known as paralinguistics. Paralanguage refers to the non-verbal elements of communication used to modify meaning and convey emotion. Paralanguage may be expressed consciously or unconsciously, and it includes the pitch, volume, and, in some cases, intonation of speech. The paralinguistic properties of speech are very important in human communication. There are no utterances that lack paralinguistic properties, since speech requires the presence of a voice, which can be modulated.

Communicating is culture [3]. It means that the culture we live in determines the way we communicate as well as the way we communicate modifies our culture. Edward T. Hall in his book "Understanding cultural differences" comes to the conclusion that communication and culture are inseparable [8]. It was E. Hall who originated a new field of study and research, called intercultural communication. Intercultural communication, often used synonymously with cross-cultural communication, tries to understand how people from different countries and cultures behave, communicate and perceive the world around them. Intercultural communication also includes anthropology, cultural studies and psychology issues.

Analyzing professional discourse we can define it as the language produced by professionals. Defining professional discourse P. Linell (2001) says that it can be divided into three categories:

(1) Intraprofessional discourse, or discourse within a specific profession, such as communication among academics;

(2) Interprofessional discourse, or discourse between individuals or representatives of different professions, such as communication between medical doctors and pharmaceutical sales persons, or between accountants and engineers; and

(3) Professional-lay discourse, such as communication between lawyers and their clients, or between advertisers and their potential customers [9].

Analysis of professional discourse has been widely related to teaching of English for specific purposes in Britain and the European continent and the teaching of composition or rhetoric in the USA.

The book 'Classroom Discourse: The Language of Teaching and Learning' by Courtney B. Cazden [10] deals with classroom discourse investigated within the framework of applied linguistics in terms of sharing time, the structure of lessons and its variations, differential treatment, ways of talking in the classroom and student 
learning from the point of view of cognitive processes and contextual influences of peer interactions.

The article "Approaches to natural language discourse processing" by Paul Mc Kevitt, Derek Partridge, and Yorick Wilks is worth paying attention to since as stated by its authors, 'theories and implementations of discourse processing will not only enable people to communicate better with computers, but also enable computers to better communicate with people' [11]. Natural-language processing i.e. processing language by computer, being one of the most important and difficult problems related to Artificial Intelligence concerns building theories and models of how individual utterances form a coherent and rational discourse. Theories, models as well as natural-language processing implementations investigate coherence by analyzing discourse meaning, structure, and intention. The latter is of primary importance, since according to a central principle of the theory coherence of natural-language dialogue can be modeled by analyzing sequences of intentions.

Tim Wharton in the chapter "Linguistic action theories of communication" published in the book Theories and Models of Communication regards a more action-oriented account of communication and treats the study of language or discourse as-action [12, p. 254].

ESP discourse study being of multitasking character is aimed at promoting understanding and professional development by performing several functions: learning interaction, sharing information, mutual cooperation etc.

Speaking about the role of language in knowledge construction M. Gail Jones and Laura Brader-Araje in their article "The Impact of Constructivism on Education: Language, Discourse, and Meaning" argue that "language forms the foundation of an individual's conceptual ecology as well as the means of conceptual growth" $[13$, p. 4]. They state that discourse (both oral and written) focuses the attention of students "on how they know what they know and how their knowledge connects to larger ideas, other domains, and the word beyond the classroom".

The article "Finding the Organization in the Communication: Discourse as Action and Sensemaking' by James R. Taylor and Daniel Robichaud reads that "the language environment frames conversations and reflects the sensemaking practices and habits of interpretation of organization members dealing with their immediate material/social purposes" [14].

Four characteristic features for studying language and communication at work dealing with different theoretical and methodological approaches are pointed out in the book "Language and Communication at Work: Discourse, Narrativity, and Organizing" edited by François Cooren, Eero Vaara, Ann Langley, Haridimos Tsoukas:

1) interest in the communicative structure of organization;

2) communicative practices;

3) both temporal aspects and dynamics;

4) language and communication placed and regarded in socio-material context $[15, \mathrm{p} .1]$.

Conclusions. The theory of communication being directly related to discourse in general and professional discourse in particular is part and parcel of the cognitive process. Professional discourse belonging to verbal communication based on words, refers to speaking, reading, writing and aural comprehension. All these aspects should be paid attention to in the process of professional discourse studies.

Theoretical findings should be incorporated into the curriculum of the courses dealing with professional discourse practical applica- tion issues: "English for specific purposes", "English for Academics", "Professional English", "Rhetoric", "Intercultural Communication" etc.

\section{References:}

1. Yu Genyuan. The Basic Theories of Applied Linguistics. URL: https:// en.cnki.com.cn/Article_en/CJFDTotal-YYYY200201005.htm.

2. François Cooren. Communication Theory at the Center: Ventriloquism and the Communicative Constitution of Reality. Journal of Communication. 2012. Vol. 62. Issue 1. P. 1-20. DOI: https://doi.org/ 10.1111/j.1460-2466.2011.01622.x.

3. Szopski, M. Komunikowanie międzykulturowe. Warszawa : Wyd. WSiP, 2005. $140 \mathrm{~s}$.

4. Morris D. Catwatching. New York, 2005. 144 p.

5. Yule G. The Study of Language. $4^{\text {th }}$ ed. New York - CUP, 2010. $307 \mathrm{p}$.

6. Fromkin V., Rodman R., Hyams N. An Introduction to language. $9^{\text {th }}$ ed. USA, 2010. $507 \mathrm{p}$.

7. Nęcki Z. Komunikacja międzyludzka. Kraków : Wyd. Profesjonalnej Szkoły Biznesu, 1996. 295 p.

8. Hall E., Hall M. Understanding cultural differences. Yarmouth ME, Intercultural Press, 1990. $190 \mathrm{p}$.

9. Linell P. Approaching dialogue, talk, interaction and context in dialogical perspectives. New York : Benjamins publishing company, 2001. $348 \mathrm{p}$.

10. Cazden, Courtney B. Classroom Discourse: The Language of Teaching and Learning. URL: https://eric.ed.gov/?id=ED288206.

11. Kevitt P.M., Partridge D., Wilks Y. Approaches to natural language discourse processing. Artificial Intelligence Review 6. 1992. P. 333-364. DOI: https://doi.org/10.1007/BF00123689.

12. Wharton Tim. Linguistic action theories of communication. Theories and Models of Communication. 2013. P. 241-256. URL: https://www. researchgate.net/publication/306170534_Linguistic_action_theories of_communication.

13. Jones M.G., Brader-Araje L. The Impact of Constructivism on Education: Language, Discourse, and Meaning. American Communication Journal. 2002. Vol. 5. Issue 3. P. 1-10.

14. Taylor J.R., Robichaud D. Finding the Organization in the Communication: Discourse as Action and Sensemaking. $S A G E$ Journals. 2004. Vol. 11. Issue 3. P. 395-413. DOI: https://doi.org/ $10.1177 \% 2 \mathrm{~F} 1350508404041999$.

15. Cooren F., Vaara E., Langley A., Tsoukas H. Language and Communication at Work: Discourse, Narrativity, and Organizing. Oxford : Oxford University Press, 2014. 376 p.

Байбакова І. М., Гасько О. Л. Теорія мовної комунікації в межах фахового дискурсу

Анотація. Статтю присвячено теорії комунікації, яка розглядається в контексті вивчення фахового дискурсу, що $\epsilon$ невіддільною частиною когнітивного процесу та стосується прикладних аспектів, безпосередньо пов'язаних із професійною діяльністю. Вирізняючись унікальною розумовою здатністю, характерною лише для людей, мова $є$ складною системою, яка містить звуки, письмові символи / друковані знаки, а також граматичні правила, що використовуються в процесі спілкування для поширення інформації, обміну думками та вираження почуттів. Треба враховувати відмінні риси людської мови, а саме: рефлексивність, уявне переміщення, довільність, продуктивність, культурну наступність і дуальність, оскільки спілкування не може існувати без знання мови. Теорія спілкування безпосередньо пов'язана 3 дискурсом загалом і фаховим дискурсом зокрема. Останній, що належить до вербальної комунікації або словесного спілкування, належить до мовлення, читання, письма 
та аудіювання. На всі ці аспекти треба звертати увагу в процесі вивчення фахового дискурсу. Дослідження дискурсу, що займається аналізом використання розмовного або письмового мовлення в соціальному комунікативному контексті щодо когнітивного процесу, також спирається на такі чинники, як структура уроків / ii варіації, диференційоване ставлення, спільний час тощо. Беручи за основу теорію комунікації, вивчення фахового дискурсу, спрямоване на засвоєння: 1) внутрішньо професійного дискурсу, тобто дискурсу в межах певної професії, що передає спілкування серед науковців; 2) міжпрофесійного дискурсу, тобто дискурсу між особами - представниками різних професій; 3) фахового дискурсу, що зображає, наприклад, спілкування юристів / їхніх клієнтів або рекламодавців / потенційних замовників. Результати теоретичного вивчення фахового дискурсу, а також відповідні прикладні аспекти як невіддільна частина навчальної програми повинні бути впроваджені в курси «Англійська мова фахового спрямування», «Англійська мова академічного спілкування», «Професійна англійська мова», «Риторика», «Міжкультурна комунікація» тощо.

Ключові слова: теорія комунікації, прикладна лінгвістика, міжкультурна комунікація, фаховий дискурс, когнітивний процес. 